\title{
Modelling the influence of environmental factors on the physiological status of the Pacific oyster Crassostrea gigas in an estuarine embayment; The Baie des Veys (France)
}

\author{
Karine Grangeré ${ }^{\mathrm{a}, \mathrm{b},{ }^{*}}$, Alain Ménesguen ${ }^{\mathrm{a}}$, Sébastien Lefebvre ${ }^{\mathrm{b}}$, Cédric Bacher $^{\mathrm{a}}$ and Stéphane \\ Pouvreau ${ }^{\mathrm{C}}$
}

\author{
a IFREMER, Département Dynamiques de l'Environnement côtier, Technopôle Brest-Iroise, z.i. Pointe du diable, \\ B.P. 70, 29280 Plouzané, France \\ ${ }^{\mathrm{b}}$ UMR 100 IFREMER-UCBN PE2M Physiologie et Ecophysiologie des Mollusques Marins, Laboratoire de \\ Biologie et Biotechnologies Marines, Université de Caen Basse-Normandie, Esplanade de la Paix, 14032 Caen \\ cedex, France \\ ${ }^{\mathrm{c}}$ UMR 100 IFREMER-UCBN PE2M Physiologie et Ecophysiologie des Mollusques Marins, Station IFREMER \\ d'Argenton, Presqu'île du Vivier, 29840 Argenton, France
}

\author{
*: Corresponding author : Karine Grangeré, Tel.: +33 2982243 34; fax: +33 2982245 48, email address : \\ karine.grangere@hotmail.fr
}

\begin{abstract}
:
It is well known that temporal changes in bivalve body mass are strongly correlated with temporal variations in water temperature and food supply. In order to study the influence of the year-to-year variability of environmental factors on oyster growth, we coupled a biogeochemical sub-model, which simulates trophic resources of oysters (i.e. phytoplankton biomass via chlorophyll a), and an ecophysiological sub-model, which simulates growth and reproduction (i.e. gametogenesis and spawning), using mechanistic bases. The biogeochemical sub-model successfully simulated phytoplankton dynamics using river nutrient inputs and meteorological factors as forcing functions. Adequate simulation of oyster growth dynamics requires a relevant food quantifier compatible with outputs of the biogeochemical sub-model (i.e. chlorophyll a concentration). We decided to use the phytoplankton carbon concentration as quantifier for food, as it is a better estimator of the energy really available to oysters. The transformation of chlorophyll a concentration into carbon concentration using a variable chlorophyll a to carbon ratio enabled us to improve the simulation of oyster growth especially during the starvation period (i.e. autumn and winter). Once validated, the coupled model was a suitable tool to study the influence of the year-to-year variability of phytoplankton dynamics and water temperature on the gonado-somatic growth of the Pacific oyster. Four years with highly contrasted meteorological conditions (river inputs, water temperature and light) 2000, 2001, 2002 and 2003 , were simulated. The years were split into two groups, wet years (2000 and 2001) and dry years (2002 and 2003). Significant variability of the response of oysters to environmental conditions was highlighted between the four scenarios. In the wet years, an increase in loadings of river nutrients and suspended particulate matter led to a shift in the initiation and the magnitude of the phytoplanktonic spring bloom, and consequently to a shift in oyster growth patterns. In contrast, in the dry years, an increase in water temperature-especially during summer-resulted in early spawning. Thus, the gonado-somatic growth pattern of oysters was shown to be sensitive to variations in river loadings and water temperature. In this context, the physiological status of oysters is discussed using a relevant indicator of energy needs.
\end{abstract}

Keywords: Biogeochemical Model; Dynamic Energy Budget model; Temperature; Food Supply; Phytoplankton Carbon Concentration; Physiological Status; France; Normandy; Baie des Veys 


\section{Introduction}

Environmental conditions are one of the identified causes of year-to-year variability of individual growth and population dynamics of estuarine benthic species. Several studies have described the influence of year-to-year environmental variability of reproductive success and biomass of macrobenthic animals living on tidal flats (e.g. Beukema, 1982, Beukema et al., 1993, 1998, Zwarts, 1991). For example, it was clearly established for numerous benthic species that cold winters enable better reproduction leading to improved recruitment success in the following summer than mild winters (Beukema et al., 1993, 1998, Philippart et al., 2003). A negative relationship was also found between temperature and bivalve mass loss in winter (Zwarts, 1991). Beukema and Cadée (1991) highlighted a strong correlation between temporal fluctuations in the growth pattern of Macoma balthica and the abundance of planktonic diatoms. It is well known that temporal variations in the body weight of numerous bivalves depend on a combination of temperature and food supply (Zwarts, 1991, Honkoop and Beukema, 1997). In estuarine ecosystems, temporal variations in food supply (i.e. phytoplankton) are highly correlated with variations in river nutrient loadings (Carmichael et al., 2004) and consequently with meteorological conditions through rainfall. However, the influence of year-to-year variability of environmental conditions (water temperature, watershed supplies or primary production) on the physiological status (growth and reproduction) of cultivated oysters has seldom been studied. For instance, some year-to-year differences in growth and mortality patterns of cultivated oysters were positively linked with the river flows in the Baie des Veys ecosystem (Normandy, France; Samain and Mc Combie, 2008, pp. 2122). The underlying hypothesis to this phenomenon is that the increase of nutrient inputs induces an increase of phytoplankton concentrations leading to a shift in oyster physiological status.

Because of the numerous processes involved, it is impossible to study the physiological response of bivalves to variations in environmental factors only using field measurements. Further insight can be gained by using a modelling tool that integrates the physiological processes of oysters (determined experimentally) and environmental processes that control oyster development. Numerous ecophysiological models describing growth and reproduction of a number of bivalve species are available in the literature. Some are net-production models (e.g. Barillé et al., 1997a, Solidoro et al., 2000, Ren and Ross, 2001, Hawkins et al., 2002), others are based on more mechanistic rules: the dynamic energy budget theory (e.g. Ren and Ross, 2005, Pouvreau et al., 2006). Although these approaches differ in how they use the 
energy acquired from the environment, a common feature to all the models is that they are forced by environmental variables (i.e. food supply and temperature). In contrast, studies describing the coupling of an ecosystem model and a bivalve ecophysiological model are less numerous. Most of these studies were conducted with the aim of improving the management of shellfish aquaculture and fishery (Dowd, 1997, Pastres et al., 2001, Marinov et al., 2007, Sato et al., 2007) or to assess the carrying capacity of cultivated ecosystems (Raillard and Ménesguen, 1994, Duarte et al., 2003, Grant et al., 2007, Ferreira et al., 2008, Spillman et al., 2008). These models link biogeochemical models of varying complexity with net production models that primarily describe the growth of total soft body weight. Reproduction and spawning are seldom explicitly modelled. Generally, spawning is considered to be a simple loss of total soft tissue weight (Hawkins et al., 2002) and its timing is often imposed as a function of field knowledge rather than of mechanistic knowledge (e.g. Raillard et al., 1993).

Whereas temperature is a well studied forcing variable, the measure of the availability of food in the environment in quantity and in quality is still a matter of debate, as is incorporation in models. Pouvreau et al. (2006) developed an ecophysiological model based on the Dynamic Energy Budget theory (Kooijmann, 2000) to simulate the growth and reproduction of the Pacific oyster Crassostrea gigas in different environmental conditions (i.e. food supply and temperature). Their model allowed adequate simulation of oyster growth and reproduction both in controlled and natural conditions using chlorophyll $a$ measurements as a proxy for food. However, in spite of these satisfactory simulations, some discrepancies (e.g. the need to adjust the half-saturation coefficient for food uptake in each experiment) led the authors to question the choice of chlorophyll $a$ as quantifier for phytoplankton abundance (Pouvreau et al., 2006). In recent studies (i.e. Bourlès et al., 2009-this issue), a new food quantifier based on cell counts (cell number per volume) was successfully applied to the oyster DEB model for different cultivated areas with different field conditions. However, as outputs of biogeochemical models are generally based on Chl $a$ and not yet on cell counts, coupling bivalve ecophysiological models and biogeochemical models does not allow the use of this kind of food quantifier.

The aim of this study was to assess the influence of inter-annual variability in environmental conditions (i.e. temperature and river inputs) on ecosystem dynamics and particularly on the physiological processes of cultivated oysters in the Baie des Veys ecosystem, an estuarine embayment in Normandy (France). Simulations were performed for 4 years with highly contrasted environmental conditions and were interpreted using the ratio between energy demand and energy input as an indicator of the oyster physiological status. 
For this purpose, we coupled a biogeochemical sub-model that simulates trophic resources of oysters and an ecophysiological sub-model that simulates oyster growth and reproduction. In a first attempt, the ecophysiological sub-model was implemented using chlorophyll $a$ as quantifier for food. Then, results were compared with simulations obtained using a new food quantifier; the phytoplankton carbon concentration which is a good estimate of the food that is really available to herbivores. Simulations of the coupled model performed using the best food quantifier were compared with available data to validate the simulation of phytoplankton and oyster growth dynamics. Once validated, this coupled model provided a suitable tool to explore the physiological response of oyster to year-to-year variations in environmental conditions.

\section{Methods}

\subsection{Study site and environmental dynamics}

The Baie des Veys is located on the French coast of the English Channel, in the western part of the Baie de Seine (Fig. 1). It is an estuarine bay under a macrotidal regime (the maximum tidal range reaches $8 \mathrm{~m}$ and the mean depth is around $5 \mathrm{~m}$ ) with an intertidal zone of around $37 \mathrm{~km}^{2}$. The intertidal area supports considerable oyster farming activity (10 500 tons of biomass) in an area of approximately 160 ha. In its southern part, the bay receives freshwater inputs from four rivers that drain a catchment area of approximately $3500 \mathrm{~km}^{2}$. The total mean discharge is around $53 \mathrm{~m}^{3} \mathrm{~s}^{-1}$ (ranging from $2.2 \mathrm{~m}^{3} \mathrm{~s}^{-1}$ at lowest water level to 400 $\mathrm{m}^{3} \mathrm{~s}^{-1}$ during floods). The Vire is the main river and supplies $40 \%$ of total inputs. The primary production dynamics of the Baie des Veys ecosystem was described in Jouenne et al. (2007). These results indicate that river nutrient inputs lead to a phytoplanktonic bloom during spring, with a prevalence of diatoms. This bloom is initially limited by a decrease in silicon availability in late spring, followed by a decrease in nitrogen concentration two weeks later. Generally, Phaeocystis cells were seen to develop between the periods of silicon and nitrogen limitation in spring.

\subsection{Modelling strategy}

The first step was to build a biogeochemical model to adequately simulate trophic resources of oysters (i.e. primary production) and water temperature as a function of 
environmental conditions (river inputs, meteorology). Our biogeochemical model was based on models previously developed by Ménesguen and Hoch (1997), Guillaud et al. (2000) and Cugier et al. (2005) (see § 2.3). The second step was to build an ecophysiological model to simulate oyster growth and reproduction as a function of trophic resources and water temperature. For this purpose, we used the oyster DEB model developed by Pouvreau et al. (2006) which was modified in order to improve the coupling with the biogeochemical model (see $\S 2.6$ and 2.7). The final step was to couple the two sub-models to create a suitable tool to simulate temporal variations in oyster physiological status as a function of environmental conditions (river inputs, water temperature). The coupled model was called the ecosystem model throughout the paper.

The coupling had to take into account interactions between the oysters and the environment. It was essential to choose the best food quantifier compatible with the biogeochemical model. Thus, the ecophysiological model was initially validated separately using different food quantifiers based on field measurements (i.e. chlorophyll $a$, phytoplankton carbon concentration). Then the oyster model was implemented in the biogeochemical model using the best food quantifier identified.

\subsection{The biogeochemical model}

The physical sub-model is a simple one-box model. The box corresponds to the mean features of the area whose location can be seen in Fig. 1. The surface area is $50 \mathrm{~km}^{2}$, the depth $5 \mathrm{~m}$, and the residence time 5 days (Grangeré, unpublished data). Residence time was obtained using a hydrodynamic model especially developed for this area. The value used in this study corresponds to an average residence time calculated from different scenarios of environmental conditions (river flows, wind speed and direction). Salinity and temperature measured out in the bay revealed neither thermal nor haline stratification (Jouenne et al., 2007). Furthermore, the strong hydrodynamic regime observed close to the bay and the shallow bathymetry led us to assume that the water column is vertically mixed. Consequently, only one vertical layer is taken into account in the model. The evolution of state variables in the sediment is simulated using a sediment box. Physical exchanges between water and sediment are mainly diffusion for dissolved variables and erosion/deposition for particulate variables.

The biogeochemical sub-model used in this study is based on a NPZD model (nutrients, phytoplankton, zooplankton and detritus) expressed in nitrogen units. The conceptual structure of the model is presented in Fig. 2 and state variables are listed in Table 1. According to 
Jouenne et al. (2007), in this ecosystem, two nutrients limit phytoplanktonic growth: nitrogen and silicon. In the model, dissolved inorganic nitrogen (DIN) is split into two state variables: nitrate and ammonium. To the best of our knowledge, no study has revealed any influence of phosphorus on primary production in the Baie des Veys. Thus, the model simulates only the nitrogen and silicon biogeochemical cycles in the water column and the sediment. The dominance of diatoms in this ecosystem (Jouenne et al., 2007) led us to select only this phytoplanktonic group. Calibration and validation of primary production processes were performed using field measurements of primary production detailed in another study (Grangeré et al., 2009).

Both the grazing of diatoms by zooplankton in the water column and the consumption of phytoplankton by cultivated oysters are modelled. The influence of oysters on the environment (consumption, biodeposition and excretion) and the modelling of oyster growth and reproduction are detailed from sections 2.5 to 2.7. In the benthic trophic layer, wild benthic suspension feeders are taken into account in order to reproduce existing trophic competition between wild and cultivated filter-feeders. The model also simulates salinity, temperature and Suspended Particulate Inorganic Matter (SPIM). SPIM is essential to accurately estimate the light extinction coefficient in these turbid coastal waters.

Further details on differential equations, processes and parameters, on nutrients, phytoplankton and zooplankton can be found in Guillaud et al. (2000) and in Cugier et al. (2005), and on wild benthic suspension feeders in Le Pape et al. (1999).

\subsection{Boundary conditions and forcing variables}

Two boundaries are considered, the northern one receives marine inputs from the Baie de Seine, and the southern one receives terrestrial inputs from the rivers.

Because of the limited data available close to the marine model boundary, state variable values come from outputs of the three-dimensional model of the Baie de Seine developed by Cugier et al. (2005). Concerning diatom biomass, a constant fixed value of $0.5 \mu \mathrm{mol} \mathrm{N} .^{-1}$ was imposed as boundary condition to ensure that the phytoplankton dynamics simulated by the box-model are the result of the internal box functioning rather than of the forced dynamics imposed by the boundary conditions.

River forcings were derived from measurements carried out in the four tributaries. River discharges were measured every day by the "DIrection Régional de l'ENvironnement (DIREN)”. Dissolved nutrients (inorganic nitrogen and silicate) Kjeldahl nitrogen and 
temperature were measured monthly by the “Agence de l'eau Seine-Normandie”. Detrital organic nitrogen concentrations were estimated as Kjeldahl nitrogen minus dissolved inorganic nitrogen (Ménesguen et Hoch, 1997). Initial conditions for pelagic variables were determined using field measurements. Concerning benthic variables, because of the lack of available data, initial conditions for benthic stocks (nutrients and detrital matter) were fixed equal to zero.

Meteorological forcing was provided by Météo-France at the Englesqueville-la-Percée station (north-east of the bay). Daily average measurements (sunshine duration, air temperature, air moisture, atmospheric pressure and cloud cover) or three-hourly data (wind speed and direction) were used for the calculation of sea temperature and surface wind-induced stress. Instantaneous solar irradiance was calculated from astronomic calculations corrected for cloudiness (Ménesguen and Hoch, 1997).

\subsection{The oyster ecophysiological model}

The dynamic energy budget model used in this study is based on the DEB theory developed by Kooijman (2000). General DEB theory uses several simple mechanistic rules based on physiological knowledge to describe the uptake and use of energy throughout an organism's life cycle in relation to environmental conditions (food availability and temperature). In other words, the model describes the way in which energy derived from food is used for maintenance, growth, development and reproduction (Kooijman, 2000). Pouvreau et al. (2006) applied this theory to the Pacific oyster Crassostrea gigas. All equations, processes and parameters of the oyster DEB model used in this paper are detailed in Pouvreau et al. (2006). Only the main features of the model functioning are presented here. Energy assimilated from food is initially integrated in a reserve pool. A fixed proportion of this energy is then spent on growth and maintenance and the remaining energy is spent on development in juveniles and on reproduction in adults. The energy allocated to reproduction is stored in a buffer, converted to eggs at the time of reproduction, and emptied at spawning. Spawning depends on two parameters: the gonado-somatic index (i.e. the ratio between energy allocated to the reproduction buffer and total energy in the animal) and water temperature. Threshold values of these parameters were determined as a function of the reproductive cycle of the species concerned. Spawning occurs when the threshold values are reached. Under prolonged starvation and when the reserve density drops below the non-growth barrier, energy stored in the reproduction buffer is used for maintenance (Pouvreau et al., 2006) corresponding to the 
gonad resorption phenomenon. When the buffer is totally depleted, the cost of maintenance is then paid by direct shrinking of structural volume.

Three state variables are simulated: structural body volume (V), reserves (E) and reproduction buffer $\left(E_{R}\right)$ (Fig. 2 and Table 1). All are expressed in energy units (Joules). From these three state variables, two additional variables are calculated, dry flesh body weight (g) and length (cm).

\subsection{Use of a new food quantifier}

As no carbon measurements were available in this ecosystem, to investigate the influence of the phytoplankton carbon concentration as food quantifier for oyster growth, it was necessary to transform chlorophyll $a$ concentrations into carbon concentrations. First, diatom concentrations expressed in nitrogen concentrations were transformed in chlorophyll $a$ concentrations using a fixed value, N:Chl $a=0.7$ mol.g ${ }^{-1}$ (Aminot et al., 1997). Then, transformation of chlorophyll $a$ concentrations in carbon concentrations was performed using the empirical formulation of the Chl $a$ :C ratio proposed by Cloern et al. (1995). The validity of this formulation allowed us to apply it easily on data and to integrate it into the biogeochemical model without additional calibration of parameters.

$$
\text { Chla:C }=0.003+0.0154 \exp (0.050 \cdot T) \exp (-0.059 \cdot E) \min \left(\frac{N}{N+K_{N}}, \frac{S i}{S i+K_{S i}}\right)
$$

where $\mathrm{T}$ is the temperature $\left({ }^{\circ} \mathrm{C}\right), \mathrm{N}$ is the nitrogen concentration $\left(\mu \mathrm{M} \mathrm{N} \mathrm{l}^{-1}\right)$, Si is the silicate concentration $\left(\mu \mathrm{M} \mathrm{Si} \mathrm{l}^{-1}\right)$, and $\mathrm{K}_{\mathrm{N}}$ and $\mathrm{K}_{\mathrm{Si}}$ are the half saturation constants for nitrogen and

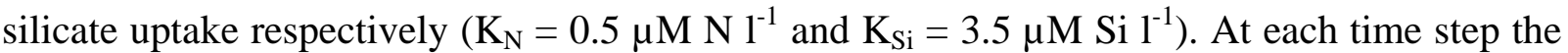
most limiting effect between nitrogen and silicon was used. $E$ is daily irradiance $\left(E \mathrm{~m}^{-2} \mathrm{~d}^{-1}\right)$ averaged over the depth of the mixed layer $(\mathrm{H})$ as follows:

$$
E=\left(\frac{E_{0}}{k H}\right)[1-\exp (-k \cdot H)]
$$

where $E_{0}\left(\mathrm{E} \mathrm{m}^{-2} \mathrm{~d}^{-1}\right)$ is daily irradiance just below the surface, $\mathrm{H}$ is the mean depth of the Baie des Veys water column, $\mathrm{H}=5 \mathrm{~m}$ and $k\left(\mathrm{~m}^{-1}\right)$ is the light attenuation coefficient. 


\subsection{Coupling with the environment}

Coupling consisted in using outputs of the biogeochemical model (i.e. chlorophyll $a$ concentration transformed into carbon concentration) as trophic resources for oysters. In parallel, outputs of the ecophysiological model (i.e. excretion and biodeposition) provided feedback on nutrient dynamics (i.e. dissolved inorganic nitrogen and detrital particulate nitrogen) simulated by the biogeochemical model.

In the DEB model, energy is acquired from the environment following up an ingestion rate IR $\left(\mathrm{J} \mathrm{d}^{-1}\right)$ which is directly proportional to surface area and depends on food availability and temperature:

$$
I R=I R_{\max } \frac{X}{X+X_{K}} V^{2 / 3} k(T)
$$

where $\mathrm{X}$ is the food concentration (i.e. phytoplankton carbon concentration $\mu \mathrm{g} \mathrm{C}^{-1}$ ), $\mathrm{X}_{K}$ is the

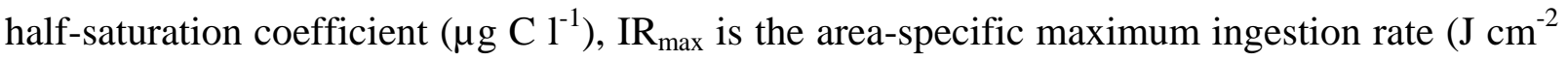
$\mathrm{d}^{-1}$ ) and $k(\mathrm{~T})$ is the temperature effect described using the Arrhenius equation (Kooijman, 2000). Assimilation rate $\mathrm{AR}\left(\mathrm{J} \mathrm{d}^{-1}\right)$ is proportional to ingestion rate:

$$
A R=a e I R
$$

where $a e=0.75$ (Van der Veer et al., 2006) is the assimilation efficiency. Thus, $75 \%$ of the energy ingested is assimilated.

The filtration rate is not explicitly taken into account in the DEB theory. Ren and Ross (2005) described the filtration rate of the greenshell mussel Perna canaliculus as a function of surface area of an organism, seston concentration and temperature. Numerous studies explored the influence of seston concentration on feeding rates in bivalves (Bayne et al., 1989, Barillé et al., 1997a, 1997b, Hawkins et al., 1998). Barillé and Prou (1993) found that below $50 \mathrm{mg} \mathrm{l}^{-1}$, the filtration rate of Crassostrea gigas was independent of seston concentrations. Measurements made in the Baie des Veys over an 18-month period showed a mean seston concentration of around $25 \mathrm{mg} \mathrm{l}^{-1}$ (Jouenne et al., 2007). Consequently, we decided to express the filtration rate as a function of the surface area of the organism, temperature and food availability:

$$
F R=I R_{\max } \frac{X}{X_{K}} V^{2 / 3} k(T)
$$


In equation 5 , the filtration rate FR $\left(\mathrm{J} \mathrm{d}^{-1}\right)$ follows the same rules as those of the ingestion rate (IR). FR is proportional to temperature, food and surface area of the organism. For lower food concentrations, the filtration rate is equal to the ingestion rate, there is no production of pseudofaeces. When the food concentration increases, the ingestion rate reaches a plateau whereas the filtration rate continues to increase, leading to production of pseudofaeces.

The influence of oysters on the environment is mainly due to biodeposition and excretion processes. Pseudofaeces and faeces are calculated indirectly by the difference between filtration and ingestion and between ingestion and assimilation respectively. In mesocosm experiments, Prins et al. (1995) estimated for the mussel that approximately $30 \%$ of primary production consumed was converted into biomass, consequently, $70 \%$ was rejected (faeces and excretion). Considering a digestion efficiency of $75 \%$ (Eq. 4), we estimated that approximately $45 \%$ of ingested nitrogen is excreted. Excreted nitrogen is directly integrated in the water column ammonium pool. In contrast, pseudofaeces and faeces are integrated in the benthic detrital pool ( $\operatorname{detN}_{\text {sed }}$ and detSi $\left.i_{\text {sed }}\right)$ and consequently, are mineralised at the same time that the sediment organic matter.

All state variables of the DEB model are expressed in energy units (Joule). In order to take into account the feedback of oysters on chlorophyll $a$ simulated by the biogeochemical model, it was necessary to convert energy into chlorophyll $a$ units. The simulated chlorophyll $a$ concentration corresponds to the biomass of mixed-species populations. Thus, it was not possible to estimate the exact energy content of chlorophyll $a$ with respect to the energy value of the phytoplanktonic pool. Consequently, we used the ratio suggested by Brown (1991) to

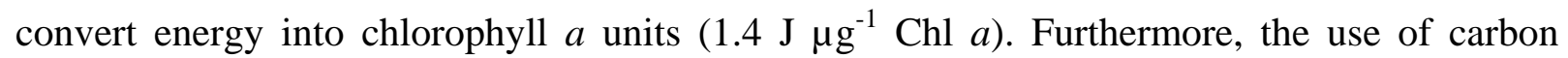
concentration as food quantifier led us to adjust the half-saturation coefficient for food uptake $\left(\mathrm{X}_{\mathrm{K}}\right)$ in terms of carbon concentration.

\subsection{Validation data set}

The coupled model was validated using measurements made in 2002 and 2003. These years were chosen due to the relative abundance of different types of data (i.e. chlorophyll $a$, nutrient concentrations, and oyster dry flesh weight). Chlorophyll $a$ and physicochemical measurements (i.e. water temperature, nitrate, ammonium and silicate) were collected every two weeks at different stations located in the bay. Two data sets were available, the first came from a monitoring network the Réseau Hydrologique Littoral Normand (RHLN) (Le Goff et al., 2005) (Grandcamp and Géfosse stations, Fig. 1), and the second from the University of 
Caen Basse-Normandie (Jouenne et al., 2007) (North, East, South and West stations, Fig. 1). At each sampling date, data were averaged spatially. The oyster farms were located in the north-eastern part of the bay (Fig. 1). Oyster data were collected from March 2002 to August 2003 at one station located in the northern part of the oyster farming area (Fig. 1). Sampling was carried out every month except during the reproductive period (late summer), when it was every two weeks. At each sampling date, 30 individuals were randomly selected. The dry flesh weight was then measured at the laboratory. The goodness-of-fit between simulations and measurements was tested according to the determination coefficient of the linear regression and using the percentage model bias defined by Allen et al. (2007).

\subsection{Simulated scenarios for year-to-year variability}

To study the influence of environmental factors on the inter-annual variability of oyster physiological status, 4 years with highly contrasted environmental and meteorological conditions were selected: 2000 and 2001, which were wet years with strong river inputs, and 2002 and 2003, which were dry years with low river inputs. 2003 was an exceptionally dry year with high water temperatures. Expected results focused on two-year-old oysters, but, to take into account variations in physiological status that had occurred the previous autumn and winter, simulations began 1 year earlier using spat as initial conditions. In each scenario, the coupled model allowed simulation of the evolution of an average individual throughout the period simulated. This implies that there is no inter-individual variability taken into account in this study. The same initial conditions were imposed to spat of ca. $0.03 \mathrm{~g}$ of dry flesh weight, corresponding to ca. $3 \mathrm{~cm}$ of shell length. All forcing variables (i.e. terrestrial and oceanic inputs, meteorological conditions) came from real data as previously explained in the section on boundary conditions. To ensure that results obtained for two-year-old oysters were independent of initial conditions at the beginning of the second year, additional simulations were performed only for two-year-old oysters using the same initial conditions. Inter-annual

variability of oyster physiological status was studied using an indicator of energy needs corresponding to the ratio between energy demand (i.e. maintenance processes) and energy input (i.e. assimilation):

$$
E_{n}=\frac{\text { energy demand }}{\text { energy input }}=\frac{\text { maintenance }}{\text { assimilation }}
$$


Based on the results obtained in the validation stage, for each scenario, chlorophyll $a$ concentrations simulated in the biogeochemical model were transformed into carbon concentrations using the variable $\mathrm{Chl} a$ :C ratio. All parameters used in this section to simulate ecosystem dynamics and oyster growth are the same as those used in the validation stage.

\section{Results}

\subsection{Validation of the biogeochemical model}

There was significant agreement between observed and simulated temperatures (Fig. 3a; Table 2), even if the simulation slightly over-estimated temperature in summer and slightly under-estimated temperature in autumn and winter. The whole temperature amplitude amounted to $15{ }^{\circ} \mathrm{C}$, with maxima of ca. $20^{\circ} \mathrm{C}$ during summer and minima of ca. $5{ }^{\circ} \mathrm{C}$ during winter.

The model successfully simulated variations in observed nitrate and silicate concentrations (Fig. 3b and d, Table 2) in spring and summer 2002 and 2003. Some discrepancies were obtained mainly during autumn and winter, where the simulation over-estimated nitrate and silicate concentrations. However, simulations were consistent with data in spring when the main nitrate and silicate limitation occurs. Model results for ammonium concentrations were generally well within the range of observed values except in autumn when the model seriously under-estimated the data (Fig. 3c, Table 2). However, on average, the ammonium concentration represented only $15 \%$ of the total concentration of dissolved inorganic nitrogen .

Overall, the simulation of the chlorophyll $a$ concentration was consistent with measurements (Table 2). The same pattern was observed for the 2 years studied (Fig. 3e). The timing of the spring bloom was well reproduced, although the magnitude was under-estimated. Furthermore, in 2003, the model failed to simulate the small autumnal bloom.

\subsection{Use of a new food quantifier}

At first, validation was performed only on the oyster DEB model using chlorophyll $a$ (Fig. 4a) and temperature measurements as forcing functions. The parameter data set used for calibration was the same as that described in Pouvreau et al. (2006). The half-saturation coefficient for chlorophyll $a$ uptake used was $\mathrm{X}_{\mathrm{K}}=4 \mu \mathrm{g}$ Chl $a \mathrm{l}^{-1}$. Overall, there were discrepancies between measured and simulated oyster dry flesh mass (Fig. 4b). Indeed, the 
simulation under-estimated the oyster dry flesh mass before spawning in spring 2002 and just after spawning in summer 2002. During autumn and winter 2002 a marked over-estimation was obtained. Furthermore, the decrease in dry flesh mass observed at this period was not reproduced by the model.

In order to improve the simulation of oyster growth, chlorophyll $a$ measurements were transformed into carbon concentrations (Fig. 4a). The time course of the Chl $a$ :C ratio was obtained using field data on nutrients, irradiance and temperature (Fig. 5). The Chl a:C ratio displayed high variability, the highest values occurred during autumn and winter (ca. $0.03 \mathrm{mg}$

Chl $a \mathrm{mg} \mathrm{C}^{-1}$ ) and the lowest during summer (ca. $0.005 \mathrm{mg} \mathrm{Chl} a \mathrm{mg} \mathrm{C}^{-1}$ ). The main difference between time variations in chlorophyll $a$ and carbon concentrations occurred in autumn and winter 2002. A chlorophyll $a$ peak was observed in September 2002, whereas no variation in carbon concentrations occurred at this time (Fig. 4a). The use of a new food quantifier required adjustment of the half-saturation coefficient for food uptake $\left(\mathrm{X}_{\mathrm{K}}\right)$, which was calibrated to 300 $\mu \mathrm{C}^{-1}$. The use of the carbon concentration instead of chlorophyll $a$ as food quantifier led to a better simulation of the oyster dry flesh mass (Fig. 4b). Whatever the food quantifier used, there were no significant differences in simulations before spawning in 2002. An inverse analysis was used to investigate the total energy input needed to accurately simulate the temporal variations in oyster growth (Fig. 6). Results highlighted the fact that during spring, energy requirements are higher than those simulated using the carbon content of phytoplankton. Nevertheless, the use of carbon led to a better representation of the autumnal growth just after spawning in 2002. Furthermore, it enabled simulation of the decrease in the oyster dry flesh mass (shrinking) that occurred during autumn and winter 2002, which was not simulated using chlorophyll $a$ as food source (Fig. 4b). Whatever the food quantifier used, the magnitude and the timing of spawning were well reproduced by the oyster DEB model (Fig. $4 b)$.

\subsection{Validation of the coupling of the biogeochemical model and the ecophysiological model}

The improved results obtained using carbon instead of chlorophyll $a$ concentration led us to apply the same method for the coupling of the oyster DEB model and the biogeochemical model. Firstly, the formulation of the Chl $a$ :C ratio was implemented in the biogeochemical model. A time course of the $\mathrm{Chl} a$ :C ratio was obtained using nutrients, irradiance and temperature simulated by the biogeochemical model (Fig. 5). The estimated Chl $a$ :C ratios based either on the variables simulated by the biogeochemical model or on measured data 
displayed the same pattern (Fig. 5). The simulation of carbon concentration by the biogeochemical model was thus consistent with the concentration obtained from data (Fig. 4a). The main difference occurred in spring 2002 and 2003 when the carbon peak was underestimated. This pattern led us to adjust the half-saturation coefficient for food uptake to 200 rather than $300 \mu \mathrm{g} \mathrm{C} \mathrm{l}^{-1}$ for simulations in the coupled model. When entered into the oyster DEB model, simulated carbon gave oyster dry flesh mass dynamics close to those obtained with carbon estimated from data for spring and summer 2002 (Fig. 4b). In contrast, in late autumn and winter 2002, the oyster dry flesh mass simulated by the ecosystem model displayed a larger decrease leading to better simulation of the starvation period. However, the simulation under-estimated oyster growth in spring 2003. In 2002, spawning was well reproduced in the coupled model. In 2003, although the timing of spawning was correctly simulated, its magnitude was twice lower than that obtained using estimation of carbon concentration from data as food quantifier.

\subsection{Influence of environmental factors: food supply and temperature}

Inter-annual variability of the environment was considered in terms of water temperature and river inputs. As a whole, inter-annual variations in water temperature displayed the same pattern in spring and autumn (Fig. 7a). The main difference occurred in summer. In 2003, the water temperature was always around $1^{\circ}$ higher than in the other years with a maximum recorded temperature of around $23^{\circ} \mathrm{C}$. Thus, the spawning threshold fixed to $19^{\circ} \mathrm{C}$ was reached at least 1 month earlier in 2003. Significant differences were observed in terms of river inputs between the 4 years studied. These differences were illustrated in terms of dissolved inorganic nitrogen inputs (Fig. 7b). The shape of the curves, as well as the interannual differences were the same for silicate and suspended particulate matter inputs. For the whole year, the highest river inputs were observed in 2001 and the lowest were observed in 2003. During the first months of the year, the increase in DIN inputs varied with the year. In 2000 and 2001, DIN inputs increased regularly until May, but the magnitude differed in the two years. In May 2001, DIN inputs reached ca. $140 \mathrm{~g} \mathrm{~N} \mathrm{~m}^{-2}$, whereas in May 2000 they only reached ca. $85 \mathrm{~g} \mathrm{~N} \mathrm{~m}^{-2}$. In 2002 and 2003, DIN inputs increased until the end of March to reach ca. $60 \mathrm{~g} \mathrm{~N} \mathrm{~m}^{-2}$.

In the same way, phytoplankton dynamics displayed two different patterns in 2000 and 2001 and in 2002 and 2003. In each group, the general shape of phytoplankton dynamics was similar (Fig. 7c). In 2000 and 2001, the spring phytoplanktonic bloom began one month later and was 
twice as high as in 2002 and 2003. In the first pattern, the maximum biomass observed during the spring bloom was around $18 \mu \mathrm{g}$ Chla $\mathrm{l}^{-1}$ whereas it reached only $12 \mu \mathrm{g}$ Chl $a \mathrm{l}^{-1}$ in the second pattern. Furthermore, during the spring bloom, a regular increase in biomass was observed in the second group, whereas in the first group, there was a sudden marked increase of phytoplankton biomass.

\subsection{Year-to-year variability of oyster physiological status}

Year-to-year variability was observed in the shape of oyster growth curves (Fig. 8). As for phytoplankton, two groups were observed. During the previous autumn and winter, the body mass was higher in 2002 and 2003 than in 2000 and 2001. During winter, a decrease in body mass was observed in all years, but was greatest in 2001. In contrast, the level of total reserves was similar in 2000, 2002, and 2003, but was lower in 2001 (Fig. 9a). A progressive shift in the beginning of the spring growth phase was observed in all 4 years studied. The earliest growth was observed in 2003 at the beginning of April, while the latest growth began in the middle of May in 2001. In each year, the beginning of the growth phase appeared to be highly correlated with the beginning of the phytoplanktonic spring bloom. The main growth period was associated with the spring bloom. At this period, the growth rate was higher in 2000 and 2001 than in 2002 and 2003 (Fig. 8). However, the level of total reserves was lowest in spring 2001 (Fig. 9a). In each year, the oyster dry flesh mass displayed a sudden sharp drop corresponding to spawning events. Its timing was highly variable depending on the year. The earliest spawning was in 2003 at the beginning of July, while the latest was in 2000, in the middle of August. In 2001 and 2002, spawning occurred at the same time, in the beginning of August. Furthermore, results showed that the later the spawning occurred, the greater the loss of mass. Significant inter-annual differences were highlighted in oyster growth after spawning. In each year, dry flesh mass increased just after spawning until September, then decreased until the end of the year. At this time, the oyster dry flesh mass was the highest in 2003, at ca. $1.4 \mathrm{~g}$, and the lowest in 2000, at ca. $1.1 \mathrm{~g}$. For all the years studied, additional simulations performed only for two-year-old oysters using the same initial conditions (data not shown) led to the same results as those shown in Fig. 8. This indicates that the shape of oyster growth curve of the second year is independent of initial conditions. Seasonal variability of the indicator of energy needs (Fig. 9b) showed that energy demand was always higher than energy input in autumn and winter, whereas the opposite pattern was observed in spring and summer. The threshold value of $E_{n}=1$, indicates that energy demand is equal to energy input. Inter-annual variability 
showed that in 2000 and 2001, the threshold value was reached sooner (ca. September $30^{\text {th }}$ ) than in 2002 and 2003 (ca. October $15^{\text {th }}$ ).

\section{Discussion}

\subsection{Validation of the biogeochemical model}

As a whole, the simulated chlorophyll $a$ and temperature led us to consider that conditions for oyster growth were appropriately simulated. However, simulations could be improved by considering the composition of phytoplanktonic populations and using a more detailed representation of physical processes.

Knowledge of the ecosystem functioning enabled us to explain the main discrepancies observed between measured and simulated phytoplankton dynamics. For example, in late spring 2002 and 2003, the highest chlorophyll $a$ concentrations measured were linked to a bloom of Phaeocystis (Jouenne et al., 2007) that occurred between silicon and nitrogen depletions.

Significant year-to-year differences obtained between nutrient concentrations in autumn and winter could be explained by variations in nutrient river inputs. 2003 was a dry year characterized by lower nutrient inputs from rivers (Jouenne et al., 2007) which occurred mainly in autumn and winter. The box model used in this study was characterized by a constant residence time of 5 days. This is a mean value corresponding to average environmental conditions (freshwater inputs and wind speed). As a result, in late 2003, this residence time could be too short to allow for an increase in nutrient standing stocks, which could have led to under-estimation of the simulated dissolved inorganic nitrogen and silicon in late summer and autumn 2003. We could have introduced a variable residence time, but, our lack of knowledge on the variability in residence time in this ecosystem led us to use the same fixed value in all simulations. To avoid such dependency between physical and biological processes, it would be necessary to use a distributed hydrodynamic model (e.g. Duarte et al., 2003, Ménesguen et al., 2007, Spillman et al., 2008).

\subsection{Use of a new food quantifier}

In the first attempt, growth and reproduction of the Pacific oyster reared in the Baie des Veys were simulated using chlorophyll $a$ measurements as quantifier for food (Pouvreau et al., 
2006). The use of chlorophyll $a$ did not produce a satisfactory simulation of the temporal variability of oyster growth in this ecosystem (Fig. 4b). Indeed, both the autumnal growth just after spawning and the starvation period were not reproduced at all. In contrast, transformation of the chlorophyll $a$ concentration into carbon concentration using a variable $\mathrm{Chl} a$ : $\mathrm{C}$ ratio enabled improvement of the simulation of oyster growth mainly during the starvation period. Many studies have described the variability of the Chl $a$ :C ratio in response to environmental conditions (Geider, 1987, Cloern et al., 1995; Geider et al., 1998, Zonneveld, 1998). The seasonal variability of the $\mathrm{Chl} a: \mathrm{C}$ ratio highlighted in this ecosystem is in accordance with that reported by Llewellyn et al. (2005) for the English Channel. Transformation of chlorophyll $a$ measurements into carbon concentrations allows the introduction of the concept of food energetic value (Platt and Irwin, 1973, Widdows and Johnson, 1988, Sarà and Mazzola, 1997, Sarà et al., 1998). The use of carbon instead of chlorophyll $a$ as a food quantifier minimized the influence of food availability in autumn and winter (The present study; Ren and Ross, 2005), which could explain the better simulation of oyster dry mass obtained using carbon rather than chlorophyll $a$ as food quantifier. Thus, the estimation of carbon content appears to be a suitable food quantifier and allows satisfactory simulation of oyster growth and reproduction.

In the same way, satisfactory simulation of oyster growth and reproduction was obtained using carbon concentration simulated within the biogeochemical model (Fig. 4b). Reproduction in terms of spawning timing was generally well reproduced in the coupled simulation. In the first step, only total spawning was simulated by the oyster DEB model depending on the gonado-somatic index and water temperature (Pouvreau et al., 2006). However, in this oyster farming area, only partial spawning is observed most of the time. Thus, a modulation of the spawning magnitude should be added in the ecophysiological model.

In spring 2002, whatever the food quantifier used the simulations under-estimated the oyster growth. Results of the inverse analysis (Fig. 6) showed that at this time, the energy required is higher than that simulated using carbon content of phytoplankton. Several studies have explored the temporal variability of oyster trophic resources (Richard et al., 1997, Riera and Richard, 1997, Marín-Leal et al., 2008). Marín-Leal et al. (2008) studied the contribution of different sources of organic matter to the diets of oysters cultivated in the Baie des Veys using stable isotopes. Overall, they showed a predominant contribution of phytoplankton to the oysters' diet and a lesser contribution of terrestrial and organic matter from the sediment (microphytobenthos and detritus). These two last organic matter sources, which were not taken into account in our model, could explain the discrepancies between measured and simulated 
oyster growth. These results could also be explained by inadequate formulation of ingestion rate. At this period, if ingestion was close to saturation, the oysters did not use all food available leading to under-estimation of oyster growth. Despite these limitations, our results indicate that using only phytoplankton in terms of carbon concentration is sufficient to explain the main pattern of oyster growth in this ecosystem.

\subsection{Influence of environmental factors: food supply and temperature}

Results obtained in the validation stage indicate that the coupled model allows satisfactory simulations of the main features of the oyster physiological responses to environmental variations. High inter-annual variability in terms of river inputs was highlighted for the 4 years studied. More precisely, river inputs can be split into two groups, 2000 and 2001, which were wet years with strong river inputs, and 2002 and 2003, which were dry years with low river inputs (Fig. 7b). In parallel, inter-annual variability of phytoplankton dynamics appeared to be highly correlated with river inputs (Fig. 7c). Wet years with strong river flows induced a significant increase in suspended particulate inorganic matter inputs in the bay, and consequently an increase in the duration of light limitation (Ebenhöh et al., 1997). This may explain the delay observed in the development of the spring bloom, which was strongly correlated with SPIM inputs. In the same way, the strong nutrient river inputs induced high phytoplankton biomass during the spring bloom (Fig. 7c) (Carmichael et al., 2004). In contrast, dry years with lower SPIM and nutrient river inputs led to an earlier and less extensive spring bloom.

A causal relationship between phytoplankton dynamics and oyster growth dynamics seems fairly obvious (Fig. 8, 2-year-old oysters). The seasonal change in body mass appeared to be correlated with variations in food availability. The main growth phase occurred in spring when phytoplankton biomass is maximum, while in late autumn and winter, oysters showed a decrease in body mass corresponding to the consumption of reserves during the starvation period associated with very low food availability (Fig. 8). Furthermore, inter-annual fluctuations in body mass were consistent with fluctuations in food supply (Fig. 7c and 8). These results are in accordance with those published by Beukema and Cadée (1991) for Macoma balthica. Nutrient river inputs appear to have an influence on the oyster growth pattern through changes in food availability (Weiss et al., 2002) mainly during the spring bloom. In wet years, body mass losses are higher during the previous autumn and winter, but mass is recovered faster once growth starts the following spring. It is well established that 
seasonal and year-to-year variability in body mass of bivalves results from a combination of temperature and food availability (Zwarts, 1991). Overall, no significant differences were highlighted in the global pattern of water temperature for the 4 years studied. Although temperature is a factor that influences all growth and reproduction rates, our results indicate that food supply is the main environmental factor that influences the seasonal and year-to-year variability of the oyster growth pattern. Cardoso et al. (2007) obtained the same results for the bivalve Macoma balthica in the Dutch Wadden Sea. Nevertheless, temperature plays a role in the reproductive pattern and more precisely in the release of gametes. Indeed, in 2003, spawning occurred 1 month earlier than in the other years. This can be explained by an increase in water temperature in summer 2003 due to exceptional climatic conditions with a maximum of around $23^{\circ} \mathrm{C}$. The effect of temperature on gonad activity in invertebrates is well known (Seed and Suchanek, 1992), and in particular, a sudden increase in temperature has been shown to initiate spawning events (Sarà et al., 1998).

\subsection{Year-to-year variability of oyster physiological status}

Our results highlighted the fact that an average individual responds in different ways to variations in environmental factors (i.e. food supply and water temperature). The shape and the magnitude of seasonal variations in oyster growth and reproduction differ from year to year. This indicates that oysters are sensitive to variations in environmental conditions and that this sensitivity may have consequences for their physiological status and even for their survival.

Temporal variations in soft body mass depend on the balance between energy demands and energy inputs (Zwarts, 1991). Thus, the ratio between these two processes seems to be a relevant indicator to identify potential periods of physiological distress. For all the years studied, results showed that energy demand was higher than energy input in autumn and winter whereas it was lower in spring and summer. In late autumn and winter, the food supply is low, and, as a result, the animals starve. When no energy is obtained from the environment, the rate of use of reserves is proportional to energetic demand, and consequently, the energy stored in reserves is used to satisfy maintenance needs. This phenomenon, which occurred in all the years studied, was more pronounced in 2001 because of the lower level of total reserves acquired the previous winter and the late occurrence of the following spring bloom (Fig. 9a). In spring 1988, in the bay of Marennes-Oléron (France), Bodoy et al. (1990) recorded a delay of approximately 2 months in the occurrence of the phytoplanktonic spring bloom due to a significant increase in river inputs. As a result of these abnormal conditions, these authors 
measured very low reserves in winter and these reserves were completely exhausted in early spring. In contrast with Marennes-Oléron bay, although the level of reserves in Baie des Veys was lower in 2001, they were never completely exhausted (Fig. 9a).

In spring and summer, the previously stored energy and the new energy acquired from the environment are used for gametogenesis (Pouvreau et al., 2006). In 2001, the lower level of reserves in autumn and winter and the increase in the duration of shrinking until the middle of spring indicated less storage in reserve cells. Consequently, in 2001, the level of reserves available for gametogenesis was lower than in the other years (Fig. 9a). Experiments conducted in controlled environments showed that reproductive effort increases with an increase in food availability (Samain and Mc Combie, 2008, pp. 81-82). A higher reproductive effort induces an increase of maintenance costs (Samain and Mc Combie, 2008, pp. 105). Whether maintenance costs are higher than energy inputs from the environment, this can induces a detrimental effect on survival for oysters (Samain and Mc Combie, 2008, pp. 68-70). In 2001, the higher trophic conditions in late spring when water temperatures increase would lead to a greater gametogenesis rate. Indeed, although the level of reserves before gametogenesis was the lowest in 2001, it reached the same level as in 2003 when spawning occurred. Whatever the year studied, the indicator of energy needs did not enable identification of a period of physiological distress during gametogenesis. Energy demands became higher than energy input only in late September in 2000 and 2001, and in the middle of October in 2002 and 2003.

In this ecosystem, a positive correlation was revealed between the increase in river flows and the increase in mortality events (Samain and Mc Combie, 2008, pp. 21-22). The highest mortality rates were recorded in 2001 (45\% mortality) and 2000 (30\%) when river inputs were the highest, while the lowest levels were recorded in 2002 (25\%) and 2003 (10\%) (Samain and Mc Combie, 2008). In this context, our results highlighted the variability in the ecophysiological response of an average individual between wet and dry years. In the Baie des Veys, oyster mortality occurred in late summer. Our results showed that the ratio of energy demand to energy inputs increased slightly earlier in wet years than in dry years. However, this difference was not sufficiently significant to conclude that physiological stress occurred in late summer 2000 and 2001. Studies of summer oyster mortality led to the conclusion that this phenomenon resulted from complex interactions between the oysters and the environment (Samain and Mc Combie, 2008). Our results highlighted the sensitivity of oysters to environmental conditions (temperature and food supply) mainly during wet years. However, all underlying physiological mechanisms were not taken into account in the ecophysiological model. In our opinion, our results represent the first step in understanding the complex 
relationships between oysters and the environment. Knowledge of the underlying physiological mechanisms is essential to fully understand the physiological response of oysters to variations in environmental conditions.

\section{Conclusion}

Year-to-year environmental fluctuation patterns tend to lead to significant variability of the physiological response of oysters. The coupled model developed in this study allowed us to describe the oyster physiological status at a macroscopic scale (river inputs, water temperature). It is a suitable tool to explore the physiological response of oysters to year-toyear variations in environmental conditions. The need to transform chlorophyll $a$ concentration into carbon concentration allowed us to estimate the quantity of food that was really available to oysters. The identification of the best food quantifier is essential to satisfactorily simulate the time course of oyster growth and reproduction. This study describes the first coupling in a shellfish ecosystem of a biogeochemical model and an ecophysiological model which simulates energy allocation between growth and reproduction, and the gametogenesis and spawning event from a mechanistic point of view. This tool could be applied to other shellfish or fish species with the aim of improving knowledge of the influence of environmental conditions on the reproductive success or survival. However, one necessary improvement will be to take into account variability among individuals to assess variations in the response of the population compared to an average individual. It would also be interesting to test more years and apply the coupled model to other ecosystems with different functioning.

\section{Acknowledgements}

This work was supported by IFREMER and by the Conseil Régional de Basse-Normandie (France). The authors would like to thank Jean-François Samain, coordinator of the MOREST project like all members of the AquaDEB research project for constructive discussions. The authors also wish to thank Daphne Goodfellow for the English assistance like two anonymous reviewers for helpful comments on the manuscript. 


\section{References}

Allen, J.I., Somerfield, P.J., Gilbert, F.J., 2007. Quantifying uncertainty in high-resolution coupled hydrodynamic-ecosystem models. Journal of Marine Systems 64, 3-14.

Aminot, A., Guillaud, J.F., Kérouel, R., 1997. La Baie de Seine : hydrologie, nutriments et chlorophylle (1978-1994). Ifremer (Ed.), Repère Océan, 14, pp. 148.

Barillé, L., Prou, J., 1993. Modeling Japanese oyster physiological processes under natural tidal variation in suspended particulate matter, ICES copenhagen (denmark).

Barillé, L., Héral, M., Barillé-Boyer, A.L., 1997a. Ecophysiological deterministic model for Crassostrea gigas in an estuarine environment. Aquatic living resources 10, 31-48.

Barillé, L., Prou, J., Héral, M., Razet, D., 1997b. Effects of high natural seston concentrations on the feeding, selection, and absorption of the oyster Crassostrea gigas (Thunberg). Journal of Experimental Marine Biology and Ecology 212, 149-172.

Bayne, B.L., Hawkins, A.J.S., Navarro, E., Iglesias, I.P., 1989. Effects of seston concentration on feeding digestion and growth in the mussel Mytilus edulis. Marine Ecology Progress Series 55, 47-54.

Beukema, J.J., 1982. Annual variation in reproductive success and biomass of the major macrozoobenthic species living in a tidal flat area of the Wadden Sea. Netherlands Journal of Sea Research 16, 37-45.

Beukema, J.J., Cadée, G.C., 1991. Growth rates of the bivalve Macoma balthica in the Wadden Sea during a period of eutrophication: relationships with concentrations of pelagic diatoms and flagellates. Marine Ecology Progress Series 68, 249-256.

Beukema, J.J., Essink, K., Michaelis, H., Zwarts, L., 1993. Year-to-year variability in the biomass of macrobenthic animals on tidal flats of the Wadden Sea: how predictable is this food source for birds? Netherlands Journal of Sea Research 31, 319-330.

Beukema, J.J., Honkoop, P.J.C., Dekker, R., 1998. Recruitment in Macoma balthica after mild and cold winters and its possible control by egg production and shrimp predation. Hydrobiologia 375-376, 23-34.

Bodoy, A., Garnier, J., Razet, D., Geairon, P., 1990. Mass Mortalities of Oysters (Crassostrea gigas) during spring 1988 in the Bay of Marennes-Oléron, Related to Environmental Conditions, ICES copenhagen (Denmark).

Bourlès, Y. Alunno-Bruscia, M., Pouvreau, S., Tollu, G., Leguay, D., Arnaud, C., Goulletquer, P., Kooijman, S.A.L.M., 2008. Modelling growth and reproduction of the Pacific oyster Crassostrea gigas: advances in the oyster-DEB model through 
application to a coastal pond. Journal of Sea Research. doi: SEARES-D-08-00093 (this issue).

Brown, M.R., 1991. The amino-acid and sugar composition of 16 species of microalgae used in mariculture. Journal of Experimental Marine Biology and Ecology 145, 79-99.

Cardoso, J.F.M.F., Witte, J.I.J., van der Veer, H.W., 2007. Habitat related growth and reproductive investment in estuarine waters, illustrated for the tellinid bivalve Macoma balthica (L.) in the western Dutch Wadden Sea. Marine Biology 152, 12711282.

Carmichael, R.H., Shriver, A.C., Valiela, I., 2004. Changes in shell and soft tissue growth, tissue composition, and survival of quahogs, Mercenaria mercenaria, and softshell clams, Mya arenaria, in response to eutrophic-driven changes in food supply and habitat. Journal of Experimental Marine Biology and Ecology 313, 75-104.

Cloern, J.E., Grenz, C., Vidergar-Lucas, L., 1995. An Empirical Model of the Phytoplankton Chlorophyll: Carbon Ratio-the Conversion factor Between Productivity and Growth Rate. Limnology and Oceanography 40, 1313-1321.

Cugier, P., Ménesguen, A., Guillaud, J.F., 2005. Three-dimensional (3D) ecological modelling of the Bay of Seine (English Channel, France). Journal of Sea Research 54, 104-124.

Dowd, M., 1997. On predicting the growth of cultured bivalves. Ecological Modelling 104, 113-131.

Duarte, P., Meneses, R., Hawkins, A.J.S., Zhu, M., Fang, J., Grant, J., 2003. Mathematical modelling to assess the carrying capacity for multi-species culture within coastal waters. Ecological Modelling 168, 109-143.

Dubois, S., Marín-Leal, J.C., Ropert, M., Lefebvre, S., 2007. Effects of oyster farming on macrofaunal assemblages associated with Lanice conchilega tubeworm populations: a trophic analysis using natural stable isotopes. Aquaculture 271, 336-349.

Ebenhöh, W., Baretta-Bekker, J.G., Baretta, J.W., 1997. The primary production module in the marine ecosystem model ERSEM II, with emphasis on the light forcing. Journal of Sea Research 38, 173-193.

Ferreira, J.G., Hawkins, A.J.S., Monteiro, P., Moore, H., Service, M., Pascoe, P.L., Ramos, L., Sequeira, A., 2008. Integrated assessment of ecosystem-scale carrying capacity in shellfish growing areas. Aquaculture 275, 138-151. 
Geider, R.J., 1987. Light and temperature dependence of the carbon to chlorophyll $a$ ratio in microalgae and cyanobacteria: implications for physiology and growth of phytoplankton. New Phytologist 106, 1-34.

Geider, R.J., MacIntyre, H.L., Kana, T.M., 1998. A dynamic regulatory model of phytoplanktonic acclimation to light, nutrients, and temperature. Limnology and Oceanography 43, 679-694.

Grangeré, K., Lefebvre, S., Ménesguen, A., Jouenne, F., 2009. On the interest of using field primary production data to calibrate phytoplankton rate processes in ecosystem models. Estuarine, Coastal and Shelf Science 81(2), 169-178.

Grant, J., Curran, K.J., Guyondet, T.L., Tita, G., Bacher, C., Koutitonsky, V., Dowd, M., 2007. A box model of carrying capacity for suspended mussel aquaculture in Lagune de la Grande-Entree, Iles-de-la-Madeleine, Quebec. Ecological Modelling 200, 193206.

Guillaud, J.F., Andrieux, F., Ménesguen, A., 2000. Biogeochemical modelling in the Bay of Seine (France): an improvement by introducing phosphorus in nutrient cycles. Journal of Marine Systems 25, 369-386.

Hawkins, A.J.S., Bayne, B.L., Bougrier, S., Heral, M., Iglesias, J.I.P., Navarro, E., Smith, R.F.M., Urrutia, M.B., 1998. Some general relationships in comparing the feeding physiology of suspension-feeding bivalve molluscs. Journal of Experimental Marine Biology and Ecology 219, 87-103.

Hawkins, A.J.S., Duarte, P., Fang, J.G., Pascoe, P.L., Zhang, J.H., Zhang, X.L., Zhu, M.Y., 2002. A functional model of responsive suspension-feeding and growth in bivalve shellfish, configured and validated for the scallop Chlamys farreri during culture in China. Journal of Experimental Marine Biology and Ecology 281, 13-40.

Honkoop, P.J.C., Beukema, J.J., 1997. Loss of body mass in winter in three intertidal bivalve species: an experimental and observational study of the interacting effects between water temperature, feeding time and feeding behaviour. Journal of Experimental Marine Biology and Ecology 212, 277-297.

Jouenne, F., Lefebvre, S., Veron, B., Lagadeuc, Y., 2007. Phytoplankton community structure and primary production in small intertidal estuarine-bay ecosystem (eastern English Channel, France). Marine Biology 151, 805-825.

Kooijman, S.A.L.M., 2000. Dynamic Energy and Mass Budgets in Biological Systems. Cambridge University Press, Cambridge (UK), 424 pp. 
Le Goff, R., Riou, P., Daniel, A., 2005. Réseau Hydrologique Littoral Normand (RHLN). Rapport 2005. Rapport Ifremer RST.LERN-05.09, pp. 137.

Le Pape, O., Jean, F., Ménesguen, A., 1999. Pelagic and benthic trophic chain coupling in a semi-enclosed coastal system, the Bay of Brest (France): a modelling approach. Marine Ecology Progress Series 189, 135-147.

Llewellyn, C.A., Fishwick, J.R., Blackford, J.C., 2005. Phytoplankton community assemblage in the English Channel: a comparison using chlorophyll $a$ derived from HPLCCHEMTAX and carbon derived from microscopy cell counts. Journal of Plankton Research 27, 103-119.

Marín Leal, J.C., Dubois, S., Orvain, F., Galois, R., Blin, J.-L., Ropert, M., Bataille, M.-P., Ourry, A., Lefebvre, S., 2008. Stable isotopes ( delta super(13)C, delta super(15)N) and modelling as tools to estimate the trophic ecology of cultivated oysters in two contrasting environments. Marine Biology 153, 673-688.

Marinov, D., Galbiati, L., Giordani, G., Viaroli, P., Norro, A., Bencivelli, S., Zaldivar, J.M., 2007. An integrated modelling approach for the management of clam farming in coastal lagoons. Aquaculture 269, 306-320.

Ménesguen, A., Hoch, T., 1997. Modelling the biogeochemical cycles of elements limiting primary production in the English Channel. 1. Role of thermohaline stratification. Marine Ecology Progress Series 146, 173-188.

Ménesguen, A., Cugier, P., Loyer, S., Vanhoutte-Brunier, A., Hoch, T., Guillaud, J.-F., Gohin, F., 2007. Two- or three-layered box-models versus fine 3D models for coastal ecological modelling? A comparative study in the English Channel (Western Europe). Journal of Marine Systems 64, 47-65.

Pastres, R., Solidoro, C., Cossarini, G., Canu, D.M., Dejak, C., 2001. Managing the rearing of Tapes philippinarum in the lagoon of Venice: a decision support system. Ecological Modelling 138, 231-245.

Philippart, C.J.M., van Aken, H.M., Beukema, J.J., Bos, O.G., Cadée, G.C., Dekker, R., 2003. Climate-related changes in recruitment of the bivalve Macoma balthica. Limnology and Oceanography 48, 2171-2185.

Platt, T., Irwin, B., 1973. Caloric content of phytoplankton. Limnology and Oceanography 18, 306-310.

Pouvreau, S., Bourlès, Y., Lefebvre, S., Gangnery, A., Alunno-Bruscia, M., 2006. Application of a dynamic energy budget model to the Pacific oyster, Crassostrea gigas, reared under various environmental conditions. Journal of Sea Research 56, 156-167. 
Prins, T.C., Escaravage, V., Smaal, A.C., Peeters, J.C.H., 1995. Nutrient cycling and phytoplankton dynamics in relation to mussel grazing in a mesocosm experiment. Ophelia 41, 289-315.

Raillard, O., Deslous-Paoli, J.M., Heral, M., Razet, D., 1993. Modelling growth and feeding of the Japanese oyster Crassostrea gigas in Marennes Oléron Bay (France). Oceanologica acta. Paris 16, 73-82.

Raillard, O., Ménesguen, A., 1994. A ecosystem box model for estimating the carrying capacity of a macrotidal shellfish system. Marine Ecology Progress Series 115, 117130.

Ren, J.S., Ross, A.H., 2001. A dynamic energy budget model of the Pacific oyster Crassostrea gigas. Ecological Modelling 142, 105-120.

Ren, J.S., Ross, A.H., 2005. Environmental influence on mussel growth: a dynamic energy budget model and its application to the greenshell mussel Perna canaliculus. Ecological Modelling 189, 347-362.

Richard, P., Riera, P., Galois, R., 1997. Temporal variations in the chemical and carbon isotope compositions of marine and terrestrial organic inputs in the Bay of MarennesOléron, France. Journal of Coastal Research 13, 879-889.

Riera, P., Richard, P., 1997. Temporal variation of delta super(13)C in particulate organic matter and oyster Crassostrea gigas in Marennes-Oléron Bay (France): effect of freshwater inflow. Marine Ecology Progress Series 147, 105-115.

Samain, J.-F., McCombie, H., 2008. Summer mortality of Pacific oyster Crassostrea gigas. The Morest project. Editions Quae, 379 pp.

Sará, G., Mazzola, A., 1997. Effects of trophic and environmental conditions on the growth of Crassostrea gigas in culture. Aquaculture 153, 81-91.

Sará, G., Manganaro, A., Cortese, G., Pusceddu, A., Mazzola, A., 1998. The relationship between food availability and growth in Mytilus galloprovincialis in the open sea (southern Mediterranean). Aquaculture 167, 1-15.

Sato, T., Imazu, Y., Sakawa, T., Kazama, T., Wakabayashi, T., Uhrenholdt, T., 2007. Modeling of integrated marine ecosystem including the generation-tracing type scallop growth model. Ecological Modelling 208, 263-285.

Seed, R., Suchanek, T.H., 1992. Population and community ecology of Mytilus. Elsevier, Amsterdam, 169 pp. 
Solidoro, C., Pastres, R., Canu, D.M., Pellizzato, M., Rossi, R., 2000. Modelling the growth of Tapes philippinarum in northern Adriatic lagoons. Marine Ecology Progress Series 199, 137-148.

Spillman, C.M., Hamilton, D.P., Hipsey, M.R., Imberger, J., 2008. A spatially resolved model of seasonal variations in phytoplankton and clam (Tapes philippinarum) biomass in Barbamarco Lagoon, Italy. Estuarine, Coastal and Shelf Science 79, 187-203.

van der Veer, H.W., Cardoso, J., van der Meer, J., 2006. The estimation of DEB parameters for various Northeast Atlantic bivalve species. Journal of Sea Research 56, 107-124.

Weiss, E.T., Carmichael, R.H., Valiela, I., 2002. The effect of nitrogen loading on the growth rates of quahogs (Mercenaria mercenaria) and soft-shell clams (Mya arenaria) through changes in food supply. Aquaculture 211, 275-289.

Widdows, J., Johnson, D., 1988. Physiological energetics of Mytilus edulis : Scope for growth. Marine Ecology Progress Series 46, 113-121.

Zonneveld, C., 1998. A cell-based model for the chlorophyll $a$ to carbon ratio in phytoplankton. Ecological Modelling 113, 55-70.

Zwarts, L., 1991. Seasonal variation in body weight of the bivalves Macoma balthica, Scrobicularia plana, Mya arenaria and Cerastoderma edule in the Dutch Wadden Sea. Netherlands Journal of Sea Research 28, 231-245. 


\section{Figure captions}

Fig 1: Map of the study area, the Baie des Veys estuary (modified after Dubois et al., 2007). The black box corresponds to the geographical area used in the box model of the Baie des Veys. The six points represent the sampling stations.

Fig 2: Conceptual diagram of the coupling of the biogeochemical sub-model and the ecophysiological sub-model for the Baie des Veys estuary.

Fig 3: Comparison of simulated (solid line) and measured (dots) water temperature (a), nitrate (b), ammonium (c), silicate (d) and phytoplanktonic chlorophyll $a$ (e) in 2002 and 2003.

Fig 4: (a) Time course of chlorophyll $a$ measurements (solid line), carbon concentration based on chlorophyll $a$ measurements and the $\mathrm{Chl} a$ :C ratio calculated from in situ data (dotted line) and carbon concentration simulated in the ecosystem model (dashed line). (b) Temporal variations in oyster dry flesh weight simulated over a period of 18 months using different food quantifiers: in situ measurements of chlorophyll $a$ (solid line), estimation of carbon concentration from chlorophyll $a$ measurements (dotted line), and simulation of carbon concentration in the ecosystem model (dashed line). Dots corresponds to oyster dry flesh weight measurements; corresponding standard deviations are indicated.

Fig 5: Time course of the Chl $a: \mathrm{C}$ ratio calculated from data measured in the Baie des Veys (solid line) and from the ecosystem model (dotted line) for 2002 and 2003 using the formulation proposed by Cloern et al. (1995).

Fig 6: Total energy input per individual obtained using the estimation of carbon concentration from chlorophyll $a$ measurement as food quantifier (dotted line) and using an inverse analysis (solid line).

Fig 7: Year-to-year variability in environmental conditions ((a) water temperature and (b) dissolved inorganic nitrogen river inputs) and chlorophyll $a$ concentrations simulated using the ecosystem model (c). In the temperature figure (a), the straight black line corresponds to the spawning threshold fixed to $19^{\circ} \mathrm{C}$. 
Fig 8: Year-to-year variability in oyster dry flesh weight simulated using the ecosystem model. For each curve, the first year corresponds to the 1-year-old oysters and the second year corresponds to the 2-year-old oysters. Years indicated in the legend correspond to the 2-yearold stage.

Fig 9: Year-to-year variability of total level of reserves (i.e. reserves + reproduction buffer) for the 2-year old stage (a). Year-to-year variability of the energy needs indicator (i.e. ratio between energy demand and energy input) (b). 
Figure 1

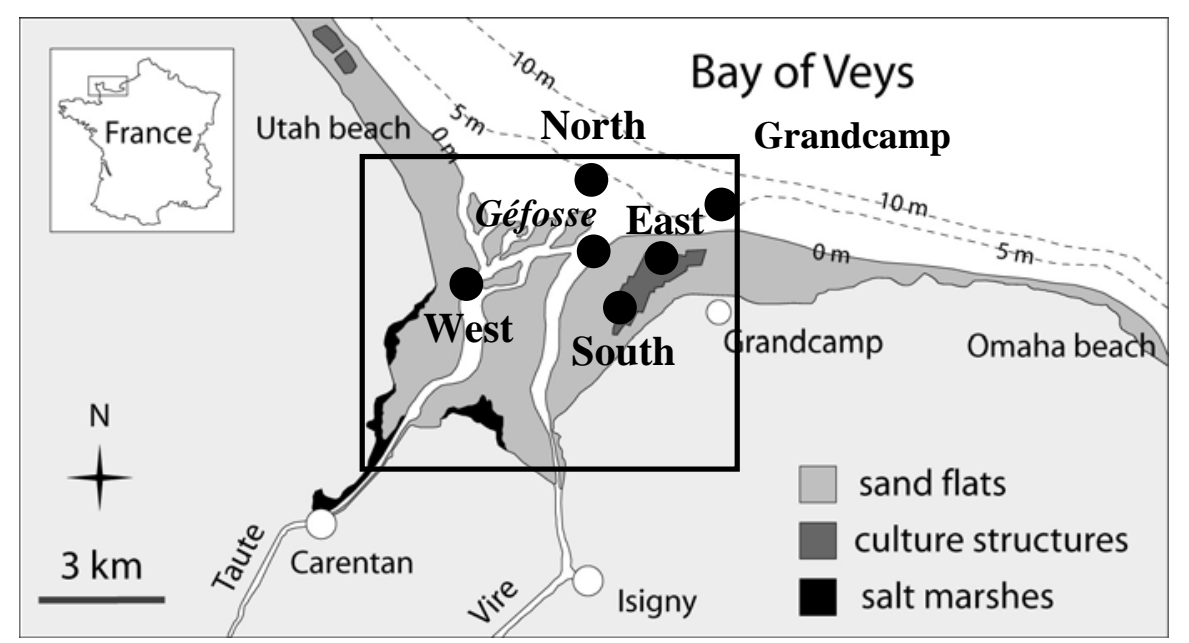


Figure 2

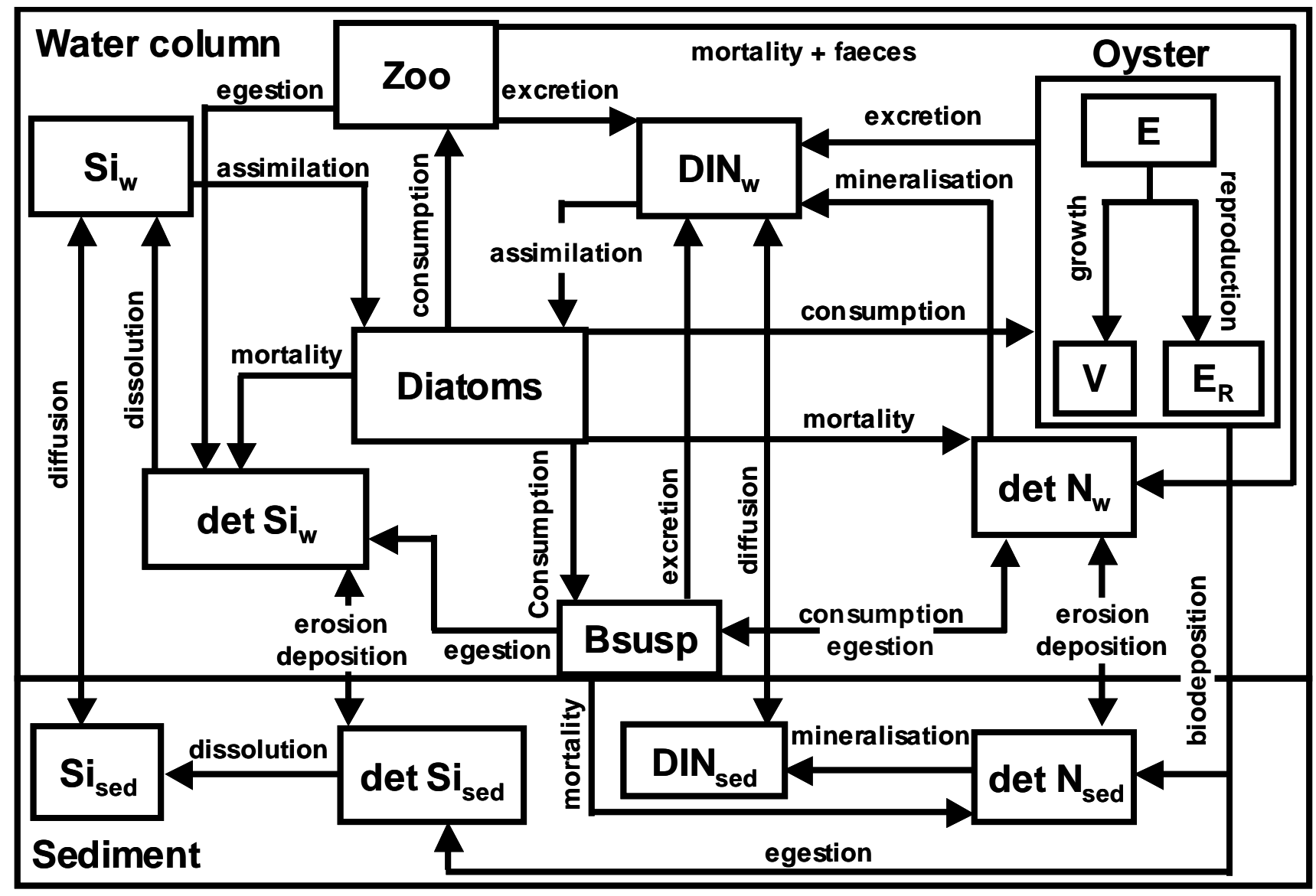


Figure 3
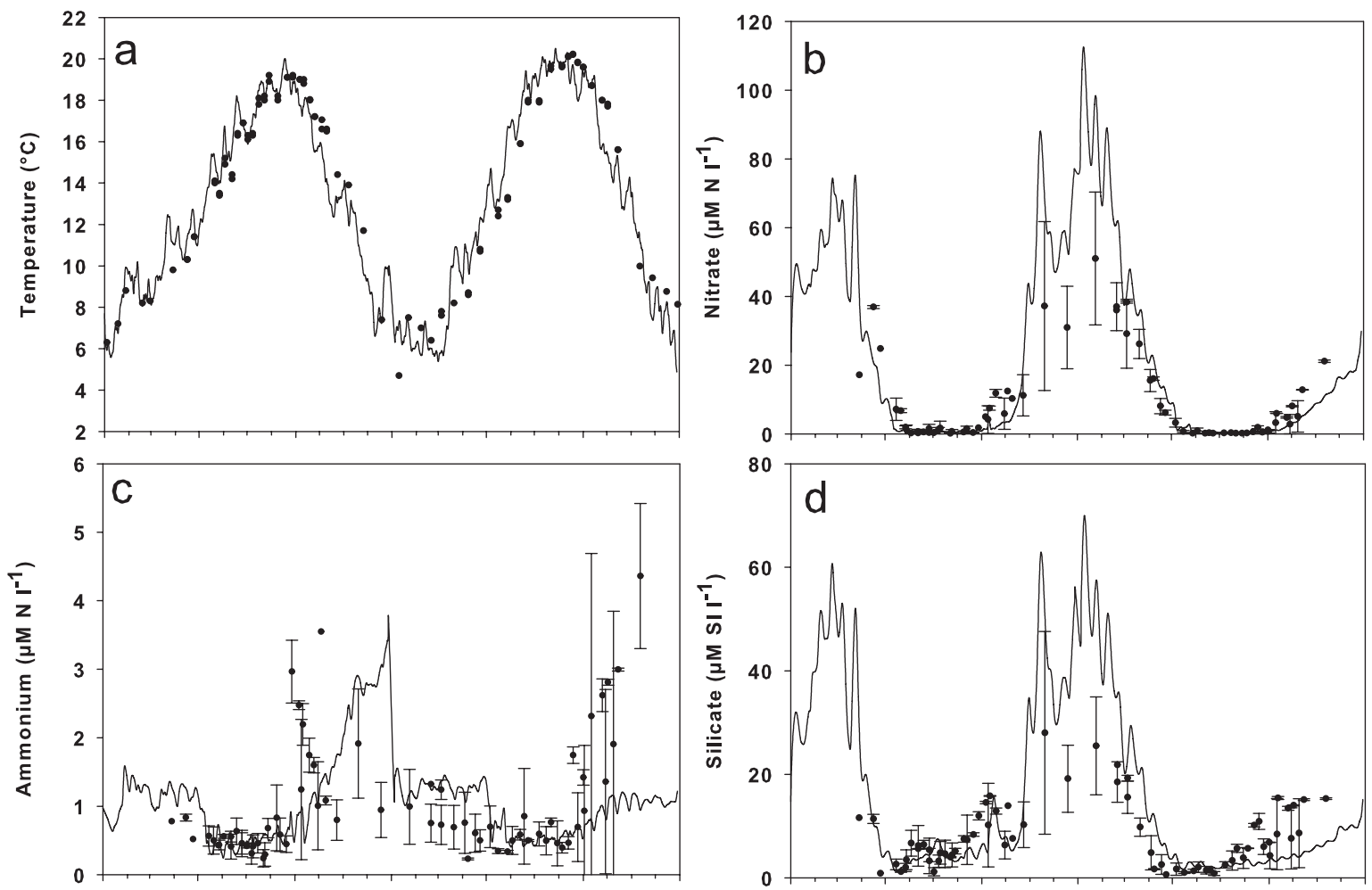

Jan 02 May 02 Sep 02 Jan 03 May 03 Sep 03 Jan 04

Jan 02 May 02 Sep 02 Jan 03 May 03 Sep 03 Jan 04 Time

Time

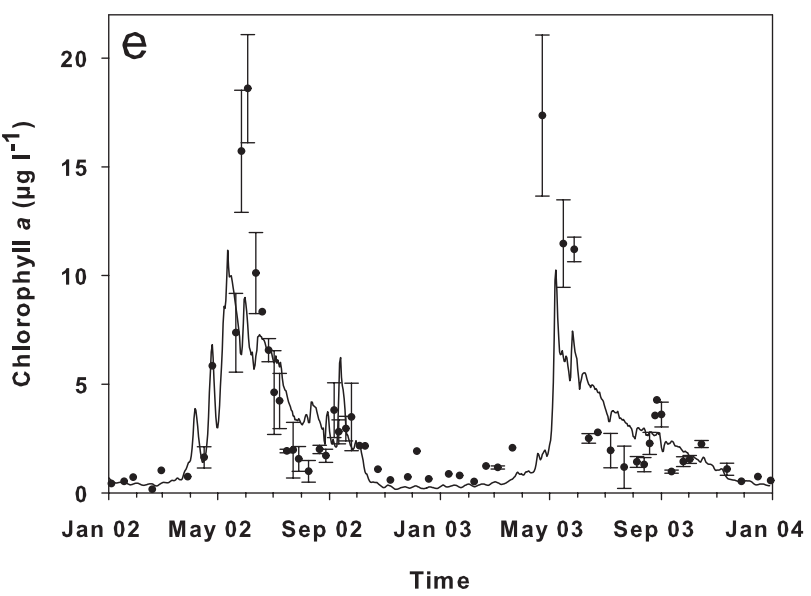


Figure 4

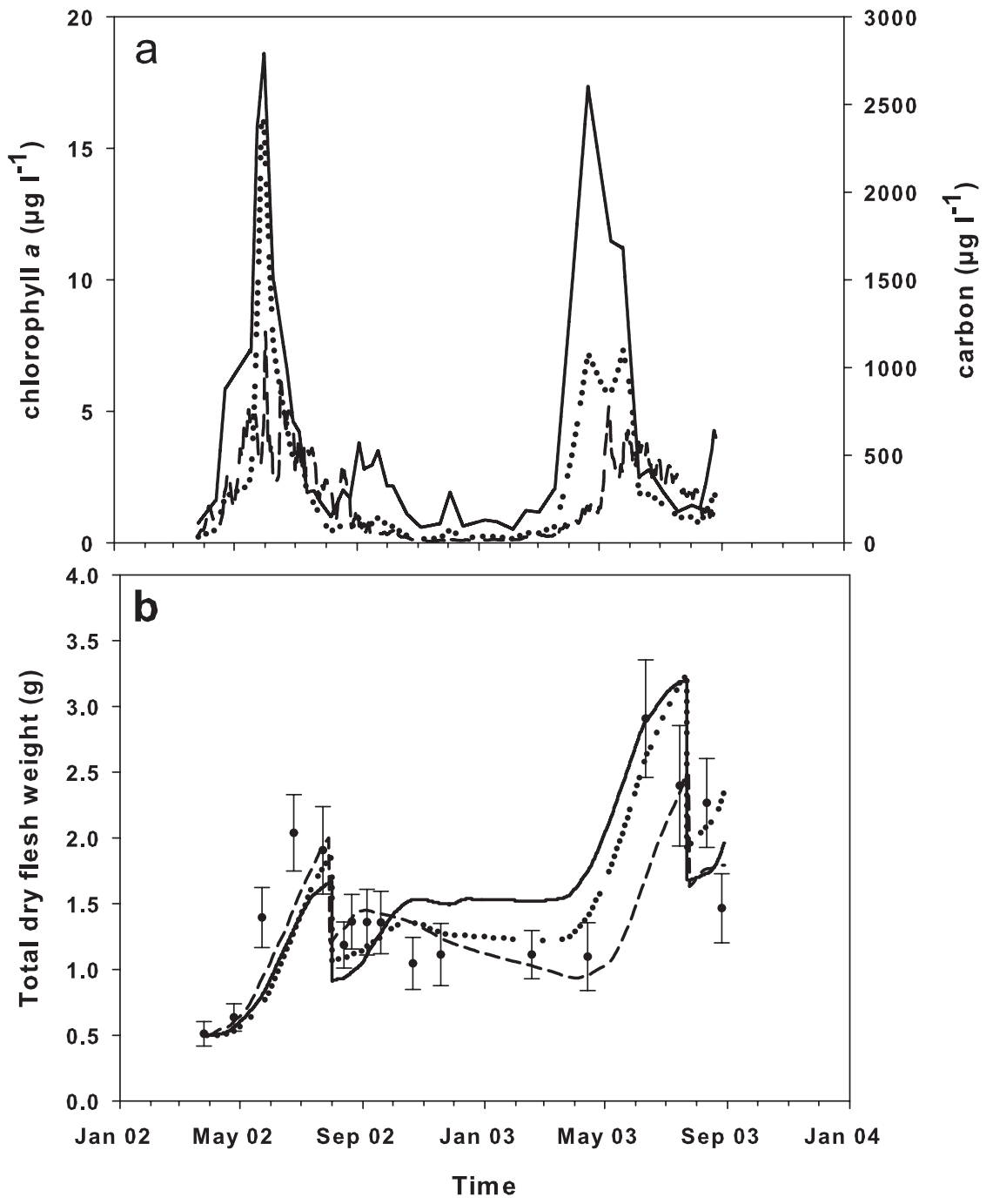


Figure 5

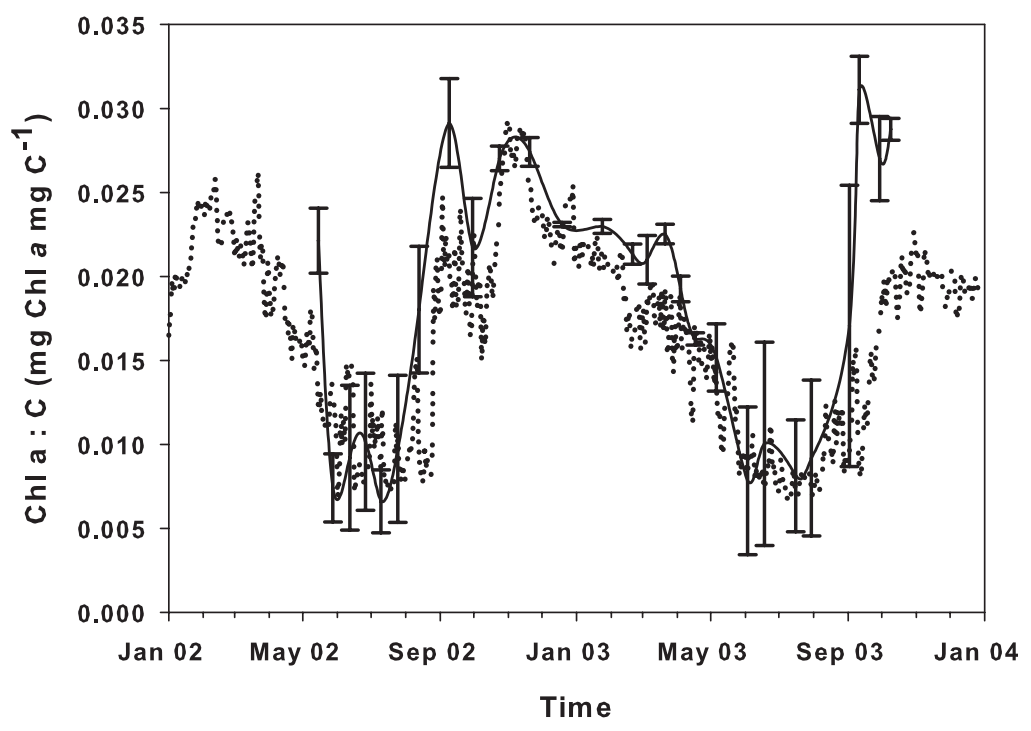


Figure 6

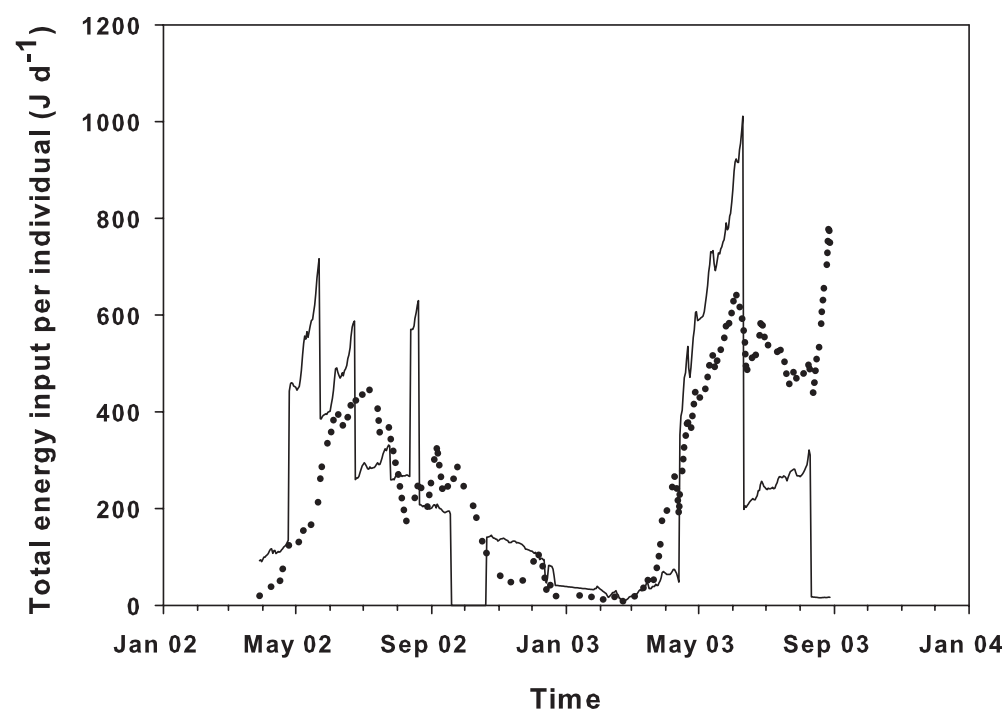


Figure 7
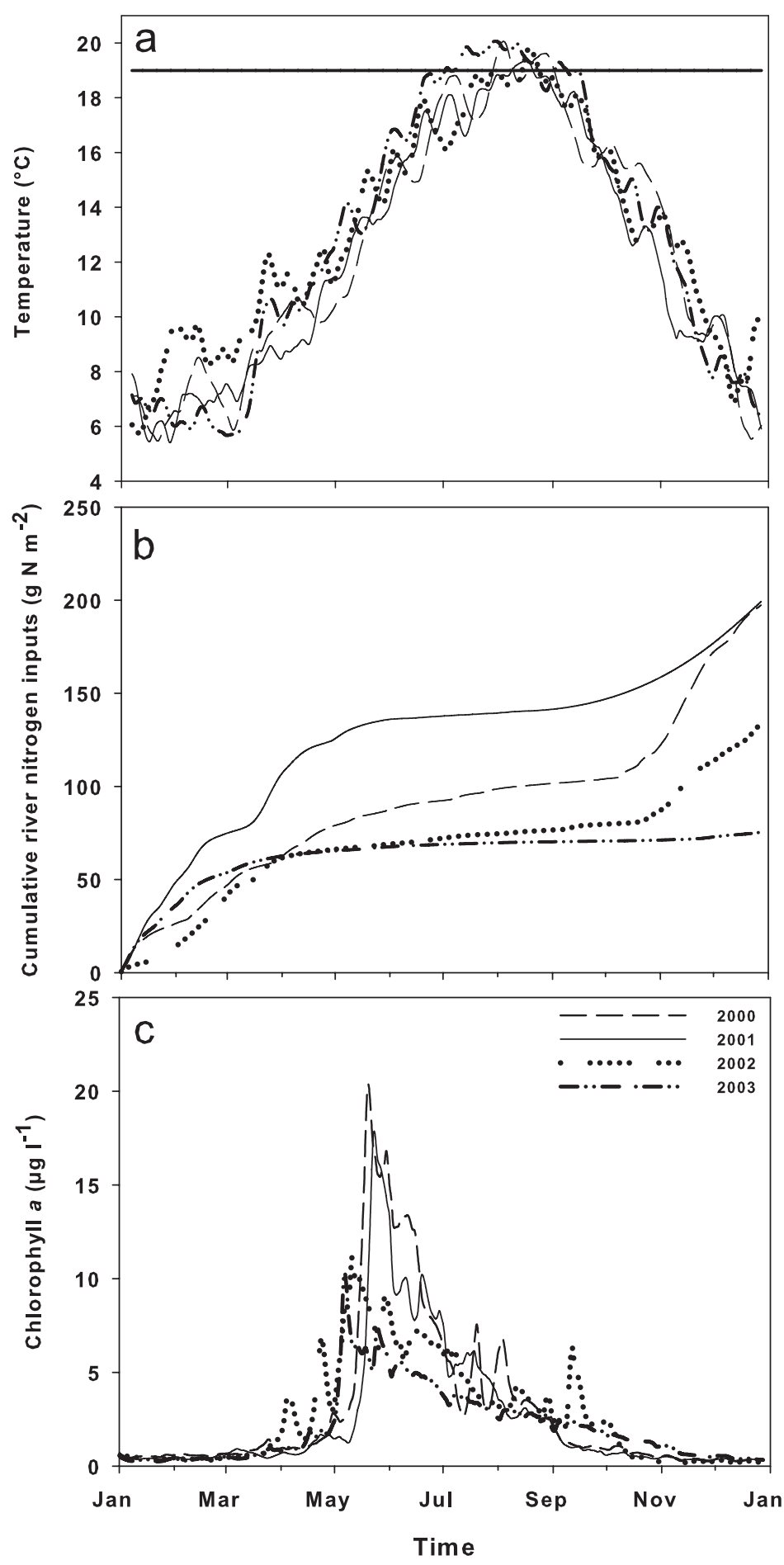
Figure 8

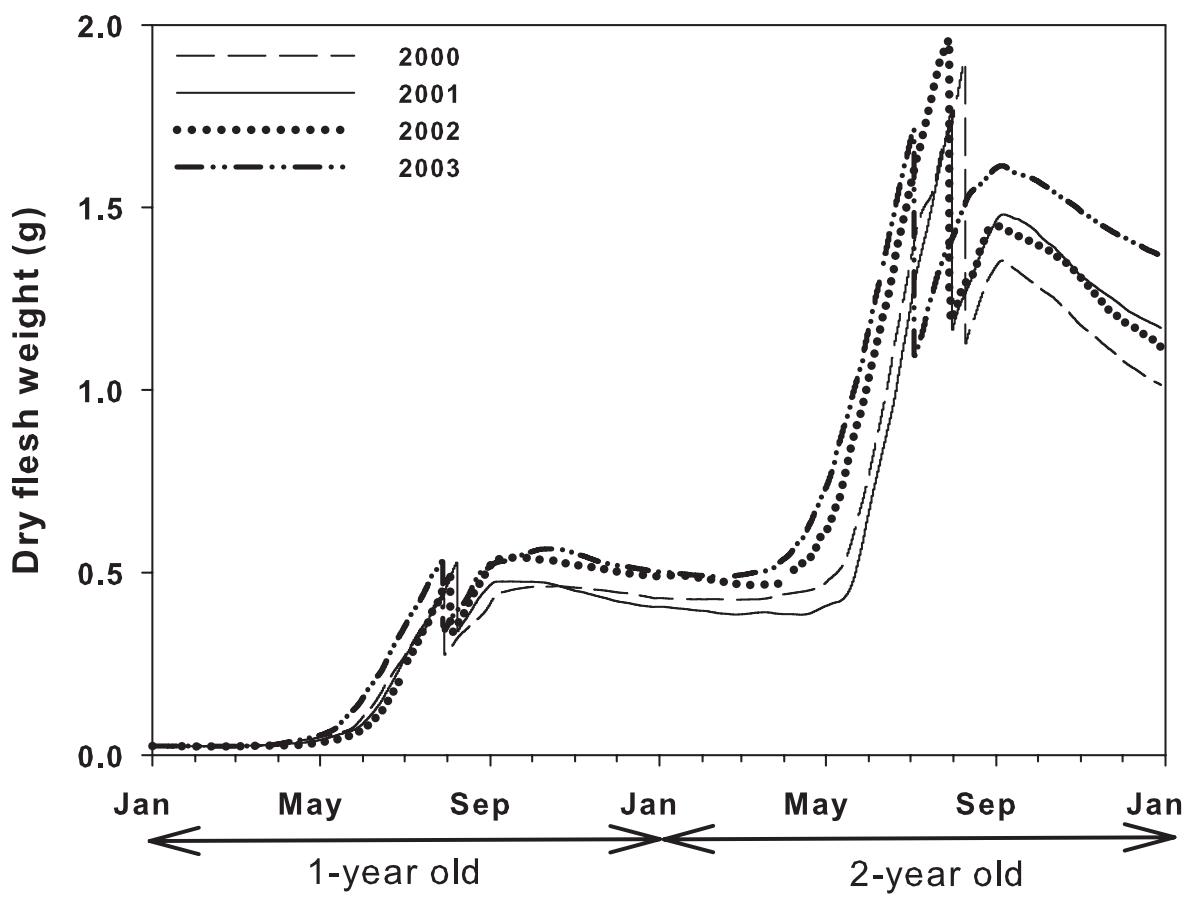


Figure 9
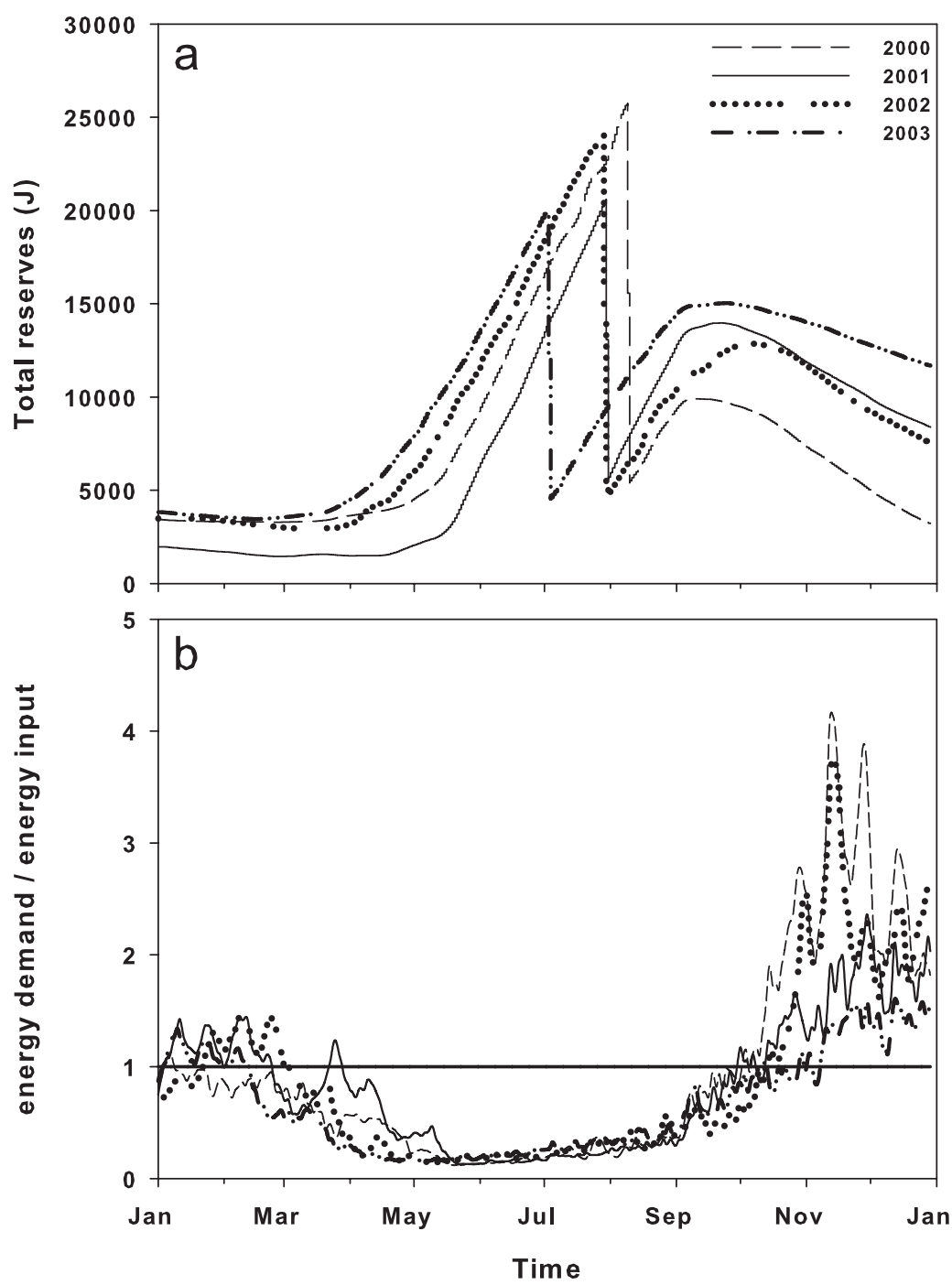
Table 1: State variables of the biogeochemical model and the ecophysiological model.

\begin{tabular}{|c|c|c|}
\hline Symbols & State variables & Units \\
\hline \multicolumn{3}{|c|}{ Biogeochemical model } \\
\hline $\mathrm{DIN}_{\mathrm{w}}$ & Pelagic dissolved inorganic nitrogen & $\mu \mathrm{mol} \mathrm{N} \mathrm{^{-1 }}$ \\
\hline $\operatorname{det} \mathrm{N}_{\mathrm{w}}$ & Pelagic detrital particulate nitrogen & $\mu \mathrm{mol} \mathrm{N} \mathrm{l^{-1 }}$ \\
\hline $\mathrm{DIN}_{\text {sed }}$ & Benthic dissolved inorganic nitrogen & $\mu \mathrm{mol} \mathrm{N} \mathrm{l^{-1 }}$ \\
\hline $\operatorname{det} \mathrm{N}_{\text {sed }}$ & Benthic detrital particulate nitrogen & $\mu \mathrm{mol} \mathrm{N} \mathrm{l^{-1 }}$ \\
\hline $\mathrm{Si}_{\mathrm{w}}$ & Pelagic silicate & $\mu \mathrm{mol} \mathrm{Si} \mathrm{l}^{-1}$ \\
\hline $\operatorname{det} \mathrm{i}_{\mathrm{w}}$ & Pelagic detrital biogenic silicon & $\mu \mathrm{mol} \mathrm{Si} \mathrm{l}^{-1}$ \\
\hline $\mathrm{Si}_{\text {sed }}$ & Benthic silicate & $\mu$ mol Si $l^{-1}$ \\
\hline $\operatorname{detSi} i_{\text {sed }}$ & Benthic detrital biogenic silicon & $\mu$ mol Si $l^{-1}$ \\
\hline Diatoms & Diatoms & $\mu \mathrm{mol} \mathrm{N} \mathrm{^{-1 }}$ \\
\hline Zoo & Zooplankton & $\mu \mathrm{mol} \mathrm{N} \mathrm{l^{-1 }}$ \\
\hline Bsusp & Wild benthic suspension feeders & g C m${ }^{-2}$ \\
\hline \multicolumn{3}{|c|}{ Ecophysiological model } \\
\hline $\mathrm{E}$ & Reserve & J.ind $^{-1}$ \\
\hline $\mathrm{V}$ & Structural body volume & J.ind $^{-1}$ \\
\hline$E_{R}$ & Reproduction buffer & J.ind $^{-1}$ \\
\hline
\end{tabular}


Table 2: Determination coefficients of the simple linear regression and percentage model bias (Allen et al., 2007) between measured and simulated state variables of the biogeochemical model (i.e. $\mathrm{Chl} a, \mathrm{NO}_{3}, \mathrm{NH}_{4}, \mathrm{SiOH}$ and Temperature) and the oyster dry weight simulated using the coupled model and carbon concentrations as food quantifier.

\begin{tabular}{lcccccc}
$\begin{array}{l}\text { Regression } \\
\text { parameters }\end{array}$ & Chl $\boldsymbol{a}$ & $\mathrm{NO}_{3}$ & $\mathbf{N H}_{\mathbf{4}}$ & $\mathrm{SiOH}$ & Temperature & $\begin{array}{c}\text { Oyster dry } \\
\text { weight }\end{array}$ \\
\hline $\mathrm{R}^{2}$ & 0.54 & 0.82 & 0.19 & 0.29 & 0.91 & 0.56 \\
p-value & $<0.001$ & $<0.001$ & $<0.005$ & $<0.001$ & $<0.001$ & $<0.001$ \\
PMB (\%) & 26.3 & -22 & 15.9 & -7.7 & 0.03 & 8.5 \\
\hline
\end{tabular}

According to Allen et al. (2007), values for the PMB are categorised as : <10 excellent; 10-20 very good; 20-40 good; $>40$ poor. 